\title{
Evaluating the Relationship Between Modern Energy Access and Social-Economic Situation of Households in Urban Areas of Turkey
}

Gülbahar BíLGiç ( $\sim$ glbhrblg@gmail.com )

Ankara Yıldırım Beyazıt Üniversitesi Mühendislik ve Doğa Bilimleri Fakültesi: Ankara Yildirim Beyazit

Universitesi Muhendislik ve Doga Bilimleri Fakultesi https://orcid.org/0000-0002-9503-5884

Mükerrem Şahin

Ankara Yıldırım Beyazıt Üniversitesi: Ankara Yildirim Beyazit Universitesi

\section{Research}

Keywords: Energy Access, Turkey, Electricity, Natural Gas, Income Level, Education

Posted Date: March 17th, 2021

DOI: https://doi.org/10.21203/rs.3.rs-281157/v1

License: (c) (i) This work is licensed under a Creative Commons Attribution 4.0 International License.

Read Full License 


\title{
Evaluating the relationship between modern energy access and social-economic situation of households in urban areas of Turkey
}

\author{
Gülbahar Bilgiç̧ Mükerrem Şahin ${ }^{1}$
}

glbhrblg@gmail.com

Department of Energy Systems Engineering, Faculty of Engineering and Natural Sciences, Ankara Yıldırım Beyazıt University, Ankara, Turkey

\begin{abstract}
This study evaluated the relationship between access to modern energy systems and the socialeconomic situation of households who live in urban zones Turkey. As a case study, in Yalova province in western Turkey, has been chosen the socio-economic and educational conditions of the households who can access clean energy services have investigated. For this purpose, we have conducted a survey covering Yalova urban areas. Results of the statistical calculations, the sample size was determined with a $6.7 \%$ acceptable error rate and a $95 \%$ confidence level, and as a result, it was seen that 214 households should be surveyed. Our results indicate the level of access of households living in Yalova to modern energy systems was changed according to their income level and education. In the city center, where access to electricity is not lacking, it has been observed that the inadequacy of households in access to electricity is only due to income difference. It has been considered that fossil fuels and derivatives are mostly consumed by low-income and low-education households. Based on this, it can be said that access to clean energy systems will increase as the income level increases, and the education level increases.
\end{abstract}

\section{Keywords: Energy Access; Turkey; Electricity; Natural Gas; Income Level; Education}

\section{Introduction}

Access to modern energy is the most important parameters for the development of countries. There is a strong relationship between access to energy and socio-economic development (UNDP, 2011) No activities can be carried out without energy in areas such as industrialization, social life, transportation, and communication. Also, when access to modern energy is insufficient, households cannot cook, heating, benefit from cultural activities, and receive a quality education. For example, fossil fuels used in rural areas, which do not have access to modern energy systems, threaten human health, education, productivity and also cause environmental pollution with the particles they emit. (Kanagawa and Nakata, June, 2008, Balachandra, 2011) Therefore, access to modern energy is one of the requirements for millions of people to reach basic living standards. According to the reports released, modern energy poverty still prevails in the developing world. Approximately 1.6 billion people in the world still do not have access to electricity (IEA, 2014). Especially in sub-Saharan Africa, which is the regional focus of IEA 2014, two out of every three people cannot access electricity. For those people who have access, electricity is often inadequate, unreliable, and one of the most expensive in the world. Also, 2.7 billion people use traditional biomass such as manure, wood, and other crops/crop residues for cooking, space heating and water heating etc. (IEA, 2014). In the same report, by 2040, a total of about one billion people are projected to gain access to electricity through renewable energy sources, but more than half a billion people will still live without electricity. 
Recent studies have increasingly focused on multidimensional aspects of poverty such as economy, education and health, and access to modern energy such as electricity and natural gas is seen as a possible solution.

Kanagawa and Nakata (2008) purposed to reveal relations between access to electricity and advancement in a socio-economic condition in rural areas in India. As a case study, they analyzed unelectrified rural areas in Assam state, India. They have developed an energy-economic model to analyze the possibility of electrification through the dissemination of electric lighting appliances. Together with multiple regression and model analysis, they concluded that with the increase in access to electricity, the literacy rate in Assam could increase from $63.3 \%$ to $74.4 \%$.

Balachandra (2011) stated that in 2005 India, only 364 million people out of the rural population of 809 million had access to electricity, and 726 million people were deprived of modern cooking fuels, and improvement work should be done in this regard. According to the author, expanding energy access to India's rural population poses a critical challenge for its government. The existence of millions of people who do not have access to electricity and rely on fossil fuels for cooking demonstrates both the failure of past policies and programs and the need for a radical restructuring of the current system. Ultimately, they propose the establishment of rural energy access authorities and energy access funds at both national and regional levels, and support for regulatory policies, capital resources, and multi-stakeholder partnership. Ultimately, they propose the establishment of rural energy access authorities and energy access funds at both national and regional levels, and support for regulatory policies, capital resources, and multi-stakeholder partnership.

Mensah et al. (2014) briefly review different types of energy access indicators and analyze access to modern energy in Ghana. The study concludes that Ghana has gained commendable access to modern energy services compared to other countries in sub-Saharan Africa.

However, the authors recommend further efforts to reach the targets for access to electricity and $50 \%$ access to LPG by 2020.

The study by Abdoulaye Fall et al. (2008) emphasized the importance of access to energy services for households and small businesses in the urban areas of Dakar, Senegal. To investigate this issue, 280 households and 70 enterprises were surveyed in Dakar's regions around 7 cities. Also, recommendations have been made to develop policy options to overcome potential barriers to energy access in these areas. The results showed that there are many barriers to modern energy access in the urban environment of Dakar. These are the misunderstanding of the characteristics of the surrounding areas, and the energy policy gap; land tenancy problems; The policy of prohibitive connection for households located away from the grid and the gradual withdrawal of state subsidy to LPG for the poor around the city.

Bhattacharyya (2011) examines India's energy consumption by different expenditure classes separately for rural and urban areas and argues that rural electrification alone is unlikely to solve the energy access problem. In the study, it has been shown that the use of firewood has decreased significantly with higher income in urban areas. However, firewood is used up to $90 \%$ in rural cooking in India, regardless of the level of expenditure (and therefore income). It has been observed that the use of electricity and LPG by higher-income classes has increased. Also, the article emphasized that the reason for the lack of access to clean energy resources in urban and rural areas is also related to poverty.

Day et al. (2016), in their study based on a statistical analysis of national survey data, estimates the extent of energy poverty in India, affecting people in rural and urban areas. According to the author, core abilities of energy, such as maintaining health, avoiding premature death, and engaging in social interaction, are the ultimate concerns of an individual or household. Therefore, they emphasize that energy services should be affordable and reliable.

Much researches have been conducted on the condition of energy consumption in rural and urban areas in developing countries. But, as shown in the above studies, access to modern energy services is still a problem with (access to electricity, clean energy sources, and LPG) today. 
In Asya, where is located in Turkey, it has been reported 100 million people cannot be reached electricity that one of the modern energy system in 2015 (IEA, 20012). However, even though the data are in this direction, no detailed research has been conducted on access to modern energy systems in our country. There is a limited number of descriptive and experimental studies in the literature. In particular, few studies deal with the socio-economic impact of the results of the statistical analysis. For this reason, in this study we researched the extent to which households living in urban areas had access to electricity and natural gas, depending on their education level and income situation. As a case study, in Yalova province in western Turkey, the socio-economic and cultural status of the households who can access clean energy services have been investigated. For this purpose, we conducted a survey covering Yalova central region.

\section{Modern energy access in Turkey \\ 2.1 Natural gas access in Turkey}

Natural gas, which is one of the modern energy sources, has a great effect on the growth of the economy, the increase in the welfare of the people, and the development of the countries. Natural gas has made an undeniable contribution to the rapid growth of our economy until today, and it continues to do so. Natural gas was used for the first time in Turkey Pinarhisar Cement Factory in 1976 (EPDK, 2014). Natural gas consumption, which started with 500 million cubic meters, was reached 45 billion cubic meters in 2013. $26 \%$ of this was used for space heating (Energy atlas, 2014). A total of 1.203.155 new subscriptions were made by the distribution companies in 2011, and approximately 93\% of these subscriptions consist of residences, $4 \%$ business offices, $2 \%$ official offices, and other subscriptions. As of the end of 2012, the total number of subscribers in provinces where natural gas service is provided has reached 9.171.624. Approximately $95 \%$ of this was as residential and 5\% non-residential (Table 1).

In 2015, there are 11.274.091 natural gas subscribers in Turkey (EPDK, 2014). Access to gas is provided in their districts with the studies carried out in recent years. Turkey's natural gas that was introduced in 1990 in general, and in the Yalova provinces began to be used in residential natural gas in 2005. The distribution zones in Yalova have laid $653 \mathrm{~km}$ of natural gas lines so far. As a result of the completion of the lines in the distribution regions, it would deliver natural gas to 130 thousand households. Table 2 was given the number of natural gas subscribers and their annual consumption in some provinces (Energy atlas, 2013).

Table 1 The amount of annual natural gas consumption per household in Turkey

\begin{tabular}{l|l|l|l|l}
\hline Years & $\begin{array}{l}\text { Number of } \\
\text { residential } \\
\text { subscribers using } \\
\text { natural gas (million) }\end{array}$ & $\begin{array}{l}\text { Annual natural gas } \\
\text { consumption } \\
\left.\mathbf{( b i l l i o n m}^{\mathbf{3}}\right)\end{array}$ & $\begin{array}{l}\text { Annual natural gas } \\
\text { consumed by the } \\
\text { household (billion } \mathbf{~ m}^{\mathbf{3}} \text { ) }\end{array}$ & $\begin{array}{l}\text { Natural gas } \\
\text { consumption per } \\
\left.\text { household } \mathbf{( m}^{\mathbf{3}}\right)\end{array}$ \\
\hline $\mathbf{2 0 1 1}$ & 7.968 .469 & 43 & 11.18 & 1403 \\
\hline $\mathbf{2 0 1 2}$ & 9.171 .624 & 44.5 & 11.57 & 1261 \\
\hline $\mathbf{2 0 1 3}$ & 9.484 .324 & 45 & 11.7 & 1233 \\
\hline $\mathbf{2 0 1 4}$ & 10.765 .377 & 45.6 & 11.85 & 1100 \\
\hline
\end{tabular}

Explanation: It is estimated that $26 \%$ of the total natural gas consumption is consumed by the residential sector (EPDK, 2014). 
Table 2 Number of natural gas subscribers and their consumption in some provinces (Energy atlas, 2013)

\begin{tabular}{l|l|l}
\hline Province name & $\begin{array}{l}\text { Number of } \\
\text { subscribers }\end{array}$ & Consumption $\left(\mathbf{m}^{3}\right)$ \\
\hline İstanbul & 3.498 .203 & 3.468 .049 .153 \\
\hline Ankara & 1.458 .975 & 1.494 .330 .548 \\
\hline Bursa & 726.768 & 585.006 .430 \\
\hline Kocaeli & 379.926 & 321.584 .999 \\
\hline İzmir & 284.139 & 321.584 .999 \\
\hline Eskişehir & 229.513 & 266.361 .644 \\
\hline Konya & 221.828 & 235.675 .201 \\
\hline Kayseri & 217.584 & 192.044 .604 \\
\hline Tekirdağ & 145.784 & 126.467 .696 \\
\hline Samsun & 123.765 & 101.289 .582 \\
\hline
\end{tabular}

\subsection{Electricity access in Turkey}

Electricity for the first time in Turkey has begun to produce from a hydroelectric power plant in 1902. Later, the installed power reached $33 \mathrm{MW}$, and the annual electricity production 45 million $\mathrm{kWh}$. In 1935, the installed power increased to $126.2 \mathrm{MW}$ and the production of electricity reached 213 million $\mathrm{kWh}$. The same year the number of provinces that can access electrical energy was 43 . In 1952, the beginning of the national energy system (Interconnected system) was established with a $154 \mathrm{kV}$ energy transmission line. While $7 \%$ of the total rural areas were electrified in 1970, by 1982 this rate reached $61 \%$. In 2015 the installed capacity of the Republic of Turkey reached 69. 681 MW (TEİAŞ, 2015, EPDK, 2015, Energy atlas, 2015). Today, Turkey has access to electricity almost the entire population. Figure 1 shows the change in electricity consumption according to the population growth between 1990 and 2015. With the increase in electrification technologies, it is seen that almost all of the population has access to electricity. Only some rural communities may have difficulty achieving universal electrification. This problem might solve with renewable energy sources and independent and mini-grid solutions such as solar and wind. 


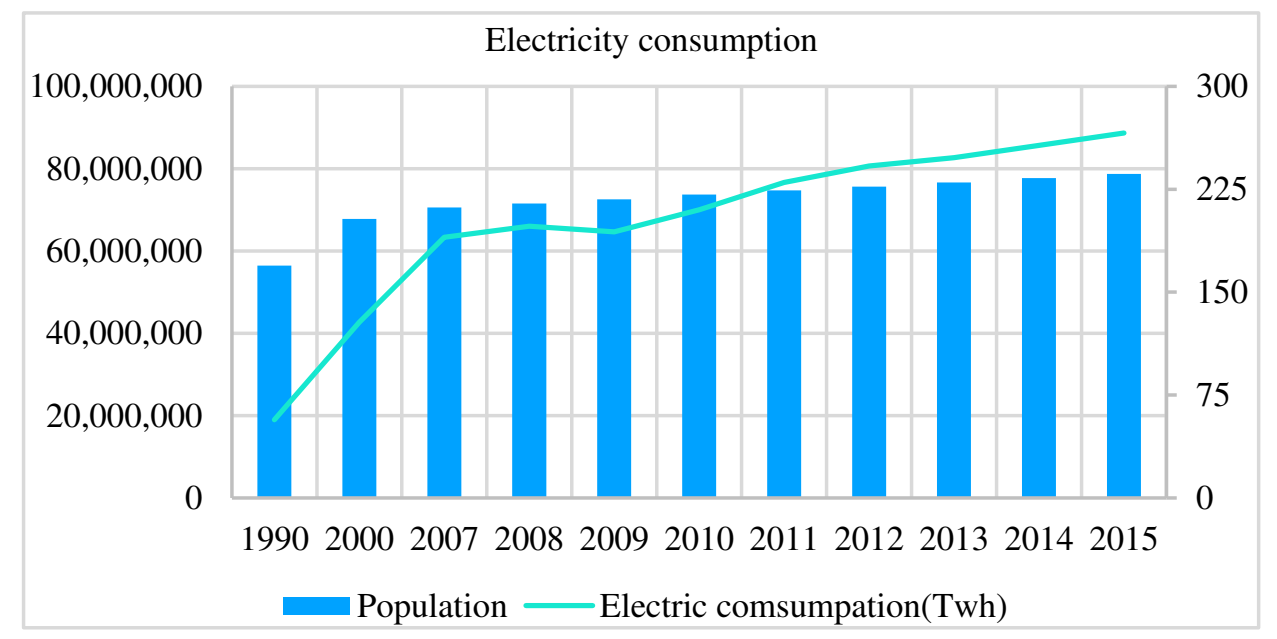

Fig. 1. Electricity access trends in Turkey

\section{Study area and research method}

\subsection{Determination of Access to Energy Systems of Households Living in Yalova Province}

Yalova is a province in western Turkey. According to the latest data, approximately 62 thousand of households lived in Yalova rural zone (Tuik, Population and Housing Research, 2011). Distribution of households in Yalova is as follows; $70.99 \%$ of them live in provincial and district centers and $29.01 \%$ in villages. Figure 2 shows research area. To determine the energy access of households in rural zones, the Yalova city center (Figure1.b) was chosen as the region where the survey was conducted.

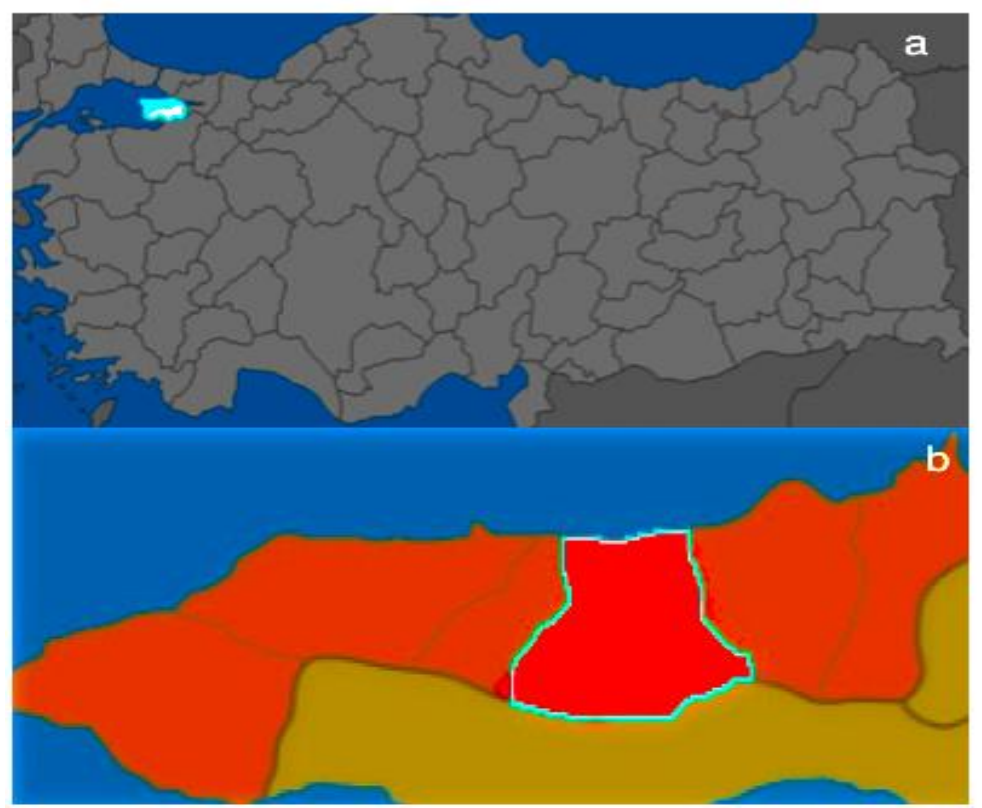

Fig. 2. Map of study area, 1.a Map of Turkey 1.b) Yalova city center area 


\subsection{Preparing the survey}

Preparing the survey is as follows; First of all, questionnaire questions were prepared. Then, it was determined where or to which region the questionnaire will be made. After determining the universe, the level of significance of the sample and the acceptable error rate was determined and how many people would join in the questionnaire. The following questions were answered by the data obtained from the survey results. These:

1.The type of fuel used by the household in general space heating

2.Relationship between household income and education level

3.Natural gas/electricity usage rate according to income level

4. Preferred fuel type according to education level

To determine whether the level of income affects energy consumption and access, the questions regarding the educational status have been asked. To obtain high efficiency from the survey study, the face-to-face survey method was preferred. Some questionnaires were collected after a few days. Also, it was said that the survey that was filled anonymously would be used in a scientific study.

\subsection{Methodology}

Almost all of the events subject to the survey research can be expressed in terms of rates. For example, the rate of using natural gas. Although the survey is carried out to obtain exact figures for these rates, the estimated values of these rates are needed in determining the sample size. These values are taken as $\mathrm{p}=0.8 / \mathrm{q}=0.2$ when the sample is homogeneous (showing similar characteristics related to the questionnaire subject), and $\mathrm{p}=0.5 / \mathrm{q}=0.5$ when it is not homogeneous (showing very different properties). Other measures to be used in determining the sample size are the sampling error, [d] and the significance level to be determined according to the frequency of occurrence (probability of occurrence) $[\alpha]$ (Balc1, 2004). Sampling is the process of selecting a part of the research that reflects all the features of the universe that is the subject of the research. While selecting the sample, it should be taken into consideration that the sample is capable of representing and that it is large enough to take into account the economics of the researches in terms of time and cost. (Arl1 and Nazik, 2001). No matter how good the sample is; Since the universe cannot be examined in its entirety, it is possible to find certain deviations between the sample values and the universe values.

In the study, the following formula was used to determine the number of samples (Balc1, 2004).

If the number of individuals in the target audience is unknown;

$\mathrm{n}=\mathrm{t}^{2} \mathrm{pq} / \mathrm{d}^{2}$

If the number of individuals in the target audience is known;

$\mathrm{N}=\mathrm{Nt}^{2} \mathrm{pq} / \mathrm{d}^{2}(\mathrm{~N}-1)+\mathrm{t}^{2} \mathrm{pq}$

$\mathrm{N}$ : Number of individuals in the target audience

$\mathrm{n}$ : Number of individuals to be sampled

p: Frequency of occurrence of the event under review (probability of occurrence)

q: Frequency of the incident under review (probability of failure)

$\mathrm{t}$ : Theoretical value found at a certain level of significance according to the table of $t$

$\mathrm{d}$ : \pm sampling error accepted according to the frequency of occurrence of the event.

If there is no $p$ estimate for the universe, $p=q=0.5$ can be taken and in this case the variance (p.q) takes the highest value $(0.25)$ and thus reaches the largest sample size.

In Table 3, sample sizes are given according to different masses for sampling errors of $\pm 3 \%, \pm 5 \%$, $\pm 10 \%$ in $95 \%$ confidence interval.

As the main population grows, the size to be sampled increases. For example, if we plan to conduct a survey on a residential area with 5000 adults, we believe that the respondents have very different 
views and features about the questionnaire. In this case, we can see from the table that you need to meet with 880 people for a questionnaire with a sampling error of $\pm 3 \%$ at the level of $\alpha=0.05$ significance. If your budget is not enough for 880 people, the accepted sampling error can be increased to $\pm 10 \%$ and this figure can be reduced to 94 . However, it is inevitable that the accuracy of the results will be reduced in this case. Instead of using the values in Table 3 directly, the sample size was calculated for certain masses (using formula 2).

Table 3 Sample sizes (Arl1 and Nazik, 2001: 77).

\begin{tabular}{|c|c|c|c|c|c|c|}
\hline \multirow[b]{3}{*}{$\begin{array}{l}\text { Target group size } \\
\text { (N) }\end{array}$} & \multicolumn{6}{|c|}{ Sample sizes for $\alpha=0.05$} \\
\hline & \multicolumn{2}{|c|}{$\begin{array}{l}\text { Sampling error } \pm 3 \% \\
\text { (d) }\end{array}$} & \multicolumn{2}{|c|}{$\begin{array}{l}\text { Sampling error } \pm 5 \% \\
\text { (d) }\end{array}$} & \multicolumn{2}{|c|}{$\begin{array}{l}\text { Sampling error } \pm 10 \% \\
\text { (d) }\end{array}$} \\
\hline & $\begin{array}{l}\mathrm{p}=0.5 \\
\mathrm{q}=0.5\end{array}$ & $\begin{array}{l}p=0.8 \\
q=0.2\end{array}$ & $\begin{array}{l}\mathrm{p}=0.5 \\
\mathrm{q}=0.5\end{array}$ & $\begin{array}{l}\mathrm{p}=0.8 \\
\mathrm{q}=0.2\end{array}$ & $\begin{array}{l}\mathrm{p}=0.5 \\
\mathrm{q}=0.5\end{array}$ & $\begin{array}{l}\mathrm{p}=0.8 \\
\mathrm{q}=0.2\end{array}$ \\
\hline 100 & 92 & 87 & 80 & 71 & 49 & 38 \\
\hline 250 & 203 & 183 & 152 & 124 & 70 & 49 \\
\hline 500 & 341 & 289 & 217 & 165 & 81 & 55 \\
\hline 750 & 441 & 358 & 254 & 185 & 85 & 57 \\
\hline 1.000 & 516 & 406 & 278 & 198 & 88 & 58 \\
\hline 2.500 & 748 & 537 & 333 & 224 & 93 & 60 \\
\hline 5.000 & 880 & 601 & 357 & 234 & 94 & 61 \\
\hline 10.000 & 964 & 639 & 370 & 240 & 95 & 61 \\
\hline 25.000 & 1023 & 665 & 378 & 244 & 96 & 61 \\
\hline 100.000 & 1056 & 678 & 383 & 245 & 96 & 61 \\
\hline 100.000 .000 & 1067 & 683 & 384 & 246 & 96 & 61 \\
\hline
\end{tabular}

\subsection{Determining the households to be surveyed.}

Since time and cost decisions limit each step of the survey process, it is extremely important to carefully estimate all costs and prepare a viable program. While determining the number of questionnaires conducted in the study, since there is no homogeneous distribution in energy access with a sampling error of $0.05 \%$ at the level of 0.05 significance, for example, the rate of natural gas use in household heating is $\mathrm{p}=0.8$ and the possibility of not using natural gas in household heating or the possibility of using coal or other fuels is taken as $q=0.2$. As a result of the researches, it has been determined that the number of households in Yalova city center is approximately 62 thousand (Tuik, Population and Housing Research, 2011). This number gives the size of the universe. Within the framework of the calculations, the sample size was determined with $6.7 \%$ acceptable error rate and $95 \%$ confidence level and as a result it was seen that 214 households should be surveyed. From here, the error rate can be reduced and the confidence interval can be increased to make the study result more realistic, but in this case, the number of surveys will increase, so the cost will increase. 
In total, 300 questionnaires were printed and distributed, some of the distributed questionnaires could not be taken back, some of them were observed to be filled in incompletely. As a result, 217 questionnaires were evaluated. Acceptable error rate and confidence interval are assumed to be the same as 214 households. While evaluating 217 questionnaires in total, the general fuel use divided into groups is divided into three groups as natural gas, wood-coal and electricity users, and natural gas users are divided into two groups as central system and individual users.

\subsection{Evaluation of the survey study}

While determining the use of natural gas and electricity per household, the statistical formulas given below are used for necessary calculations.

If calculation is made with weighted arithmetic mean:

As a non-empty data set,

$\left[x_{1}, x_{2}, \ldots, x_{n}\right]$,

weight function for each element

$\left[w_{1}, w_{2}, \ldots, w_{n}\right]$

Given as the weighted average formula.

$\bar{x}=\frac{\sum_{i=1}^{n} w_{i} x_{i}}{\sum_{i=1}^{n} w_{i}}$,

It is written more clearly,

$\bar{x}=\frac{w_{1} x_{1}+w_{2} x_{2}+\cdots+w_{n} x_{n}}{w_{1}+w_{2}+\cdots+w_{n}}$.

Normalized weighted arithmetic mean is a special weighted arithmetic mean that can be seen in practice. The weight is the special normalized weighted arithmetic mean resulting from the normalized form of the function. The normalization process is used to make the sum of the weights equal to 3 . In this case, the denominator of the weighted arithmetic average formula is equal to 3 . So the denominator:

$w_{1}+w_{2}+\cdots+w_{n}=1$

Since this is a condition, the following normalized weighted arithmetic mean is found:

$\bar{x}=w_{1} x_{1}+w_{2} x_{2}+\cdots+w_{n} x_{n}$

The steps to find out how much monthly natural gas consumption of a household in Yalova is as follows:

While making evaluations about natural gas, the weighted average of the results obtained from the questionnaires was calculated and the amount paid to monthly natural gas per household was found. It was calculated separately for the winter period (October-April) and for the summer period (MaySeptember).

The steps to find out how much a household's monthly electricity consumption is in Yalova are as follows: 
The evaluation was made among all survey groups (wood-coal, natural gas and electricity users).

The surveys are divided into three groups for transactions made according to income level:

These:

1000-2000TL $=$ Low

2000-4000TL $=$ Medium

4000-5000 TL and more $=$ High

Central system users and subscribers using individual combi boilers were evaluated together to determine the change in the amount of natural gas consumption according to income level. Operations were made through 183 questionnaires. Coal and electricity users are not included as fuel. The survey results were separated by income groups, 112 households with low income level, 73 households with medium level and 32 households with high level were found.

While examining with natural gas / electricity access / consumption status according to the level of education, all users are divided into four groups according to their education level. These are primary education (elementary + secondary school), high school, graduate, high education (master and doctor of philosophy). 92 of the respondents have primary education, 76 have high school, 46 have graduate and 3 have high education. The weighted averages of monthly electricity and natural gas consumption of these groups were made and their distribution was made in $\%$.

\section{Results}

\subsection{Determining the amount of natural gas / electricity consumed per household in Yalova}

While making evaluations in this section, natural gas users were separated from all survey groups. In the survey, the households were asked about their monthly average natural gas consumption in TL and this value was converted to $\mathrm{m}^{3}$ in calculations. The natural gas consumption of the household is calculated for two separate periods by taking the natural gas consumption for winter (October-April) and the summer period (May-September). In order to make the calculations easier, the average of the natural gas ranges was taken.

In Table $4, \mathrm{~m}^{3}$ conversion of the natural gas consumption intervals (TL) used in the survey has been made. Here, the amount of natural gas consumed monthly was calculated

Table 4 Household average monthly natural gas consumption calculation.

\begin{tabular}{|l|l|l|l|l|l|}
\hline $\begin{array}{l}\text { Natural gas } \\
\text { consumption } \\
\text { cost } \\
(\text { winter })(\mathbf{T L})\end{array}$ & $\begin{array}{l}\text { Natural gas } \\
\left.\text { amount } \mathbf{m}^{\mathbf{3}}\right)\end{array}$ & $\begin{array}{l}\text { Average } \\
\text { consumption } \\
\left(\mathbf{m}^{\mathbf{3}}\right)\end{array}$ & $\begin{array}{l}\text { Natural Gas } \\
\text { consumption } \\
\mathbf{c o s t}(\mathbf{s u m m e r}) \\
\mathbf{( T L )}\end{array}$ & $\begin{array}{l}\text { Natural gas } \\
\text { amount }\left(\mathbf{m}^{3}\right)\end{array}$ & $\begin{array}{l}\text { Average } \\
\text { consumption } \\
\left(\mathbf{m}^{\mathbf{3}}\right)\end{array}$ \\
\hline $100-150$ & $85-127$ & 106 & $10-15$ & $9-13$ & 11 \\
\hline $150-200$ & $127-170$ & 148 & $15-20$ & $13-18$ & 15.5 \\
\hline $200-250$ & $170-212$ & 190 & $20-25$ & $18-22$ & 20 \\
\hline $250-300$ & $212-255$ & 233 & $25-30$ & $22-25$ & 23.5 \\
\hline $300-350$ & $255-295$ & 275 & $30-35$ & $25-30$ & 27.5 \\
\hline
\end{tabular}

Table 5 shows the distribution of natural gas consumption for the winter period. Natural gas consumption distribution of households in the survey area in Yalova province were found for the winter period. 
Table 5 Winter gas consumption distribution

\begin{tabular}{|l|l|l|l|l|l|l|}
\hline $\begin{array}{l}\text { Natural gas } \\
\left.\text { amount } \mathbf{( m}^{3}\right)\end{array}$ & $85-127$ & $127-170$ & $170-212$ & $212-255$ & $255-295$ & Total \\
\hline Sample size & 40 & 31 & 48 & 31 & 33 & 183 \\
\hline$\%$ & 21.8 & 16.93 & 26.22 & 16.9 & 18.03 & 100 \\
\hline $\begin{array}{l}\text { Number of } \\
\text { households }\end{array}$ & 13551 & 10502 & 16262 & 10502 & 11180 & 62000 \\
\hline
\end{tabular}

Monthly natural gas consumption is found if the average natural gas consumption amounts in Table 4 are multiplied by the percentages and weighted averages in Table 5.

In other words, the average monthly natural gas consumption of a household for the winter period is $106 \times 21.8+148 \times 16.93+190 \times 26.22+233 \times 16.9+275 \times 18.03 / 100=186.94 \mathrm{~m}^{3}$.

As a result, the 6-month consumption here is found to be $1121 \mathrm{~m}^{3}$ (equation 6).

Table 6 shows the natural gas consumption values for the summer period. The calculations made for the winter period were also made for the summer period and the average natural gas consumption was found to be $21.27 \mathrm{~m}^{3}$. The average 6-month natural gas consumption of a household for the summer period is $127.6 \mathrm{~m}^{3}$. If the amount of natural gas consumed by the household during the winter and summer periods is added, the average annual natural gas consumption of a household living in Yalova is found. As a result, the annual natural gas consumption of a household is 1248.6 with $95 \%$ confidence level and $5.35 \%$ margin of error.

Table 6 Summer period natural gas consumption

\begin{tabular}{|l|l|l|l|l|l|l|}
\hline $\begin{array}{l}\text { Natural gas } \\
\text { amount }\left(\mathbf{m}^{\mathbf{3}}\right)\end{array}$ & $\mathbf{9 - 1 3}$ & $\mathbf{1 3 - 1 8}$ & $\mathbf{1 8 - 2 2}$ & $\mathbf{2 2 - 2 5}$ & $\mathbf{2 5 - 3 0}$ & Total \\
\hline Sample size & 18 & 27 & 45 & 44 & 49 & 183 \\
\hline $\boldsymbol{\%}$ & 9.83 & 14.7 & 24.5 & 24.04 & 26.78 & 100 \\
\hline $\begin{array}{l}\text { Number of } \\
\text { households }\end{array}$ & 6098 & 9147 & 15245 & 14907 & 16601 & 62000 \\
\hline
\end{tabular}

The same calculations were made to find the average annual electricity consumption of the household. The ranges and average values of electricity consumption asked in the survey are given in Table 7 . Each of the average values here has been multiplied by the weighted averages in Table 8 .

Table 7. Monthly electricity consumption of household

\begin{tabular}{|l|l|l|}
\hline $\begin{array}{l}\text { Electricity } \\
\text { consumption cost } \\
\text { (TL / month) }\end{array}$ & $\begin{array}{l}\text { Electricity } \\
\text { amount (kWh / } \\
\text { month) }\end{array}$ & $\begin{array}{l}\text { Average } \\
\text { (kWh / } \\
\text { month) }\end{array}$ \\
\hline $25-50$ & $80-160$ & 120 \\
\hline
\end{tabular}




\begin{tabular}{|l|l|l|}
\hline $50-75$ & $160-240$ & 200 \\
\hline $75-100$ & $240-320$ & 280 \\
\hline $100-125$ & $320-400$ & 320 \\
\hline
\end{tabular}

Table 8. Distribution of households according to electricity consumption intervals

\begin{tabular}{|l|l|l|l|l|l|}
\hline $\begin{array}{l}\text { Electricity } \\
\text { consumption } \\
\text { (kWh) }\end{array}$ & $\mathbf{8 0 - 1 6 0}$ & $\mathbf{1 6 0 - 2 4 0}$ & $\mathbf{2 4 0 - 3 2 0}$ & $\mathbf{3 2 0 - 4 0 0}$ & Total \\
\hline Sample size & 32 & 84 & 76 & 25 & 217 \\
\hline \% & 14.7 & 32.2 & 42.1 & 10 & 100 \\
\hline $\begin{array}{l}\text { Number of } \\
\text { households }\end{array}$ & 9920 & 19840 & 26040 & 6200 & 62000 \\
\hline
\end{tabular}

According to the survey results and calculations, the annual electricity consumption of a household living in Yalova was found to be $4061.8 \mathrm{kWh}$ based on a 5.35\% sampling error.

\subsection{Access to energy by the income level}

Education is recognized as one of the most fundamental components of poverty reduction. It has been observed that low-income households have a lower literacy rate than middle or high-income households (Kanagawa, 2008). Therefore, there is a causal relationship between education and income.

Based on this information, the education level of the household was determined according to the income level of the household before evaluating energy access by education level. While the survey, questions were asked to the households for this purpose. Figure 3 shows income distribution by the education level of households. It has been observed that $66 \%$ have low income and 23 percent have middle income those who receive primary education. If we make the general population distribution of these values based on the survey percentage, it can be assumed that 62 thousand households living in the city center of Yalova, approximately 32 thousand have low income, 22.285 have middle income and the remaining 7.714 households have the high-income group. It has been observed that those with higher education have middle and high-income levels. 


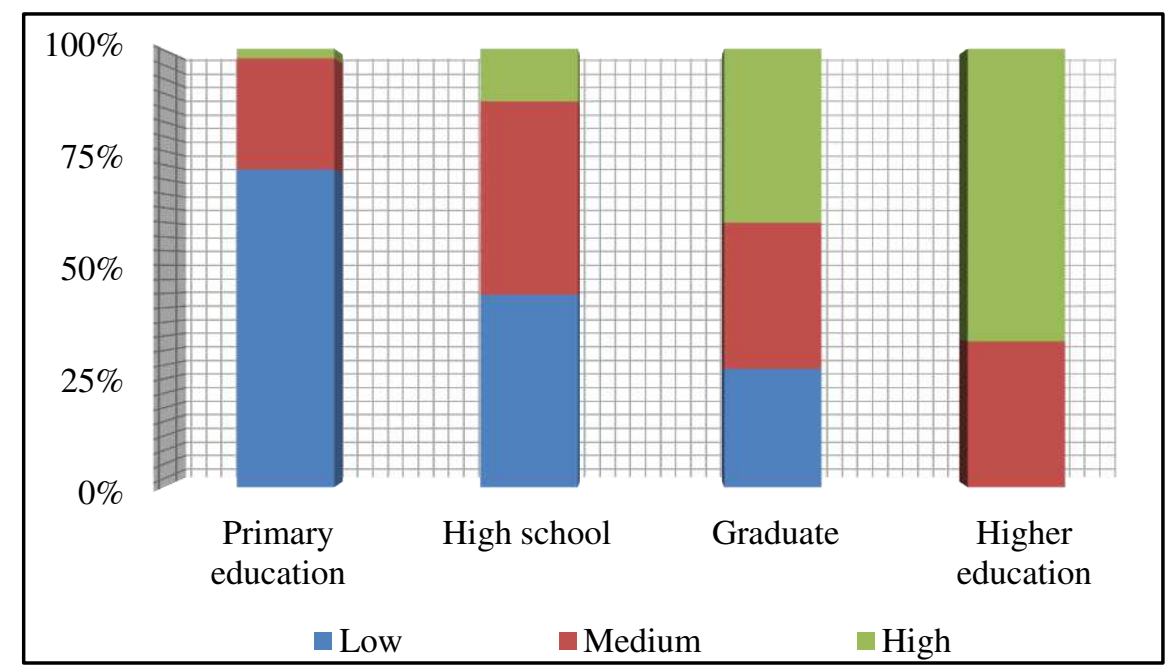

Fig. 3. Income level by educational

All questionnaire groups were examined to determine the general energy source used by households for space heating, cooking, and water heating according to their income level. In Figure 4, 58\% of fossil fuel is mostly consumed by low-income households. The majority of wood and coal users are households with low and middle-income groups. It is observed that households with an income of 4 thousand or more prefer natural gas. The results show that access to clean energy systems increases as income levels rise. However, with the increase in natural gas distribution, it is observed that the consumption of natural gas is high by households of all income levels. When energy distribution prices rise, poor households have to reduce their energy consumption. Because if they want to use the same amount of energy as high-income households, they need to give up or reduce other basic costs such as food and healthcare. This brings about inequalities. It can be concluded here that the use of natural gas by poor households is not a necessity but an obligation most of the time.

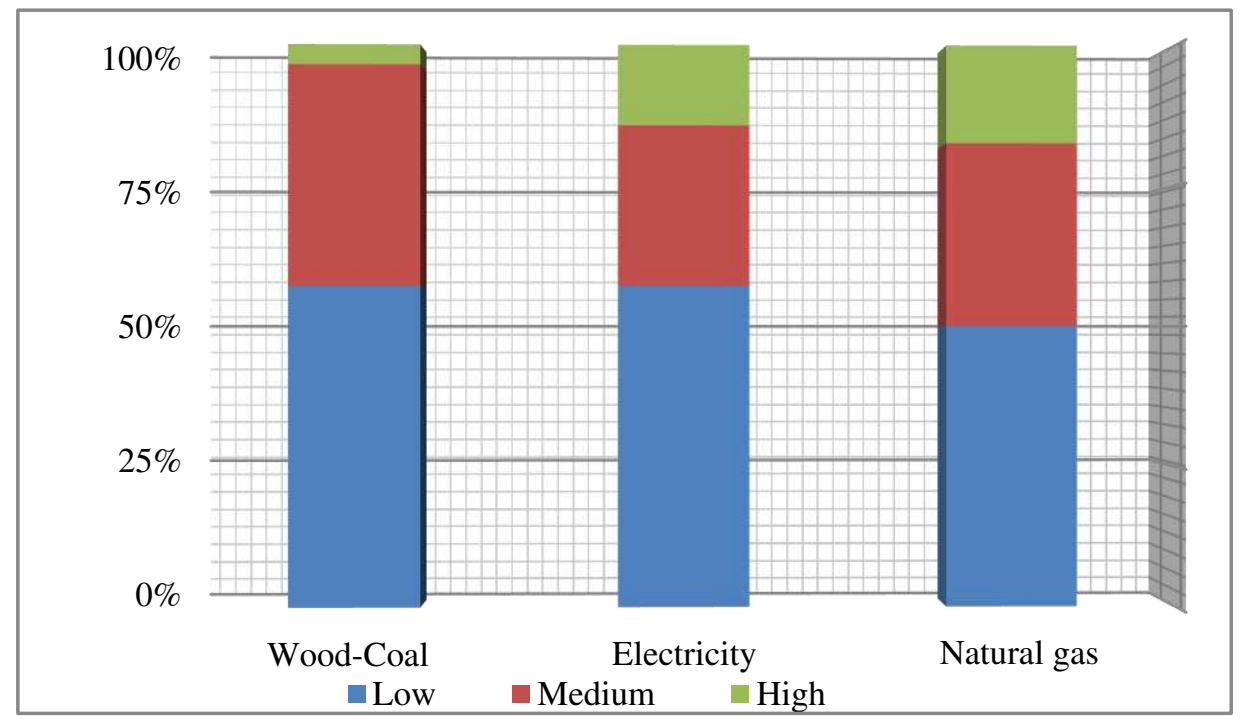

Fig. 4. General fuel consumption by income level 
The variation of household electricity usage by income level is given in Figure 5. When the access of households to electricity is examined, no households without access were found. Considering the distribution of 62 thousand households by low, middle and high income groups, it is seen that the electricity usage between 160-320 kWh is at the highest level for all groups (approximately 46 thousand households). According to the survey results, as the income level increased, the electricity consumption reached a certain level. In the figure, it is seen that electricity consumption is highest between $160 \mathrm{kWh}$ and $320 \mathrm{kWh}$ at all income levels of the household.

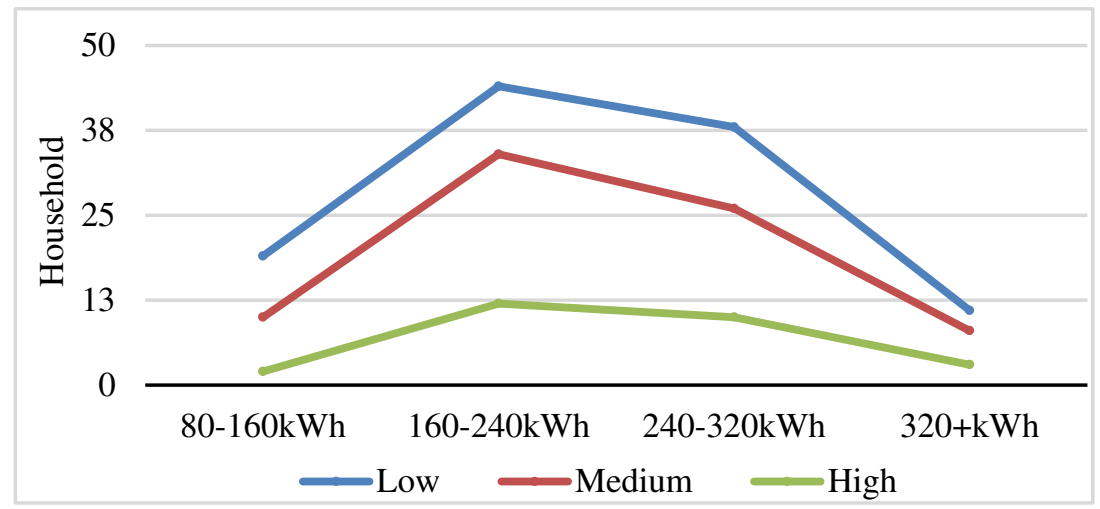

Fig. 5. Change of electricity consumption to income levels of household

In Table 4, the amount of natural gas consumed monthly was calculated before. Figure 6 shows the distribution of natural gas consumption used by households is made according to the income level. Clearly seen in the graph the highest consumption of natural gas consumption interval for all income groups is $170-212 \mathrm{~m}^{3}$. It can be concluded that the use of natural gas, like electricity, is also a basic need for all income levels and consumption increases as the income level increases, but does not change after a certain level.

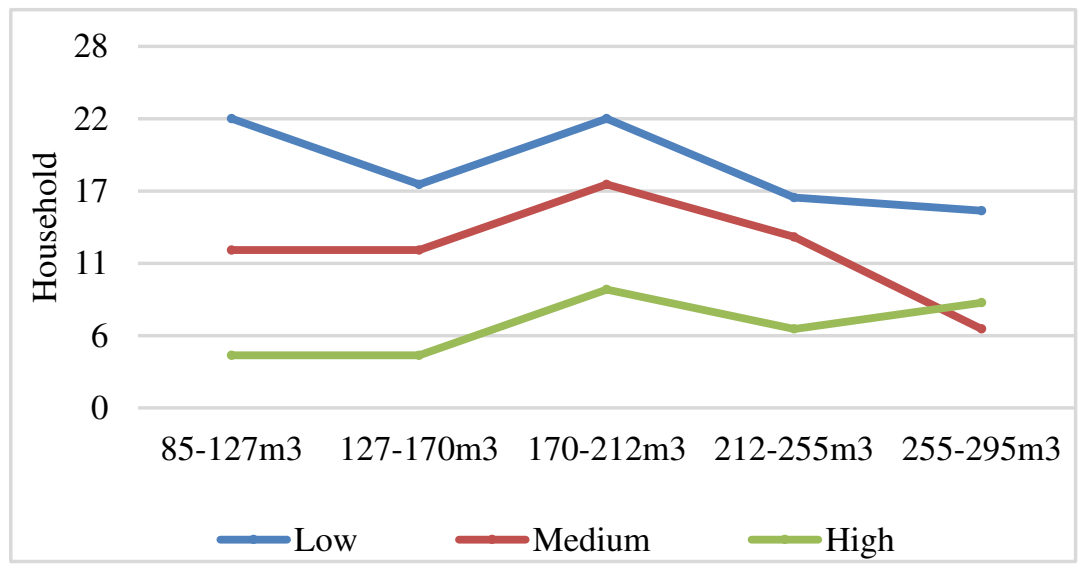

Fig. 6. Natural gas consumption according to household income level 


\subsection{Access to energy by the level of education}

Besides the effects of the economic situation on access to energy, there is also an interaction between education level and access to energy. Improving energy access, especially improving access to electricity, is an important parameter that has a profound impact on education. Due to high electrification, rural households get enough illumination to work in a home at night and can use TV, radio, and information and communication technologies for educational purposes.

Hence, access to electricity and other modern energy provided a better educational environment for households (Okada, 2004). While conducting studies in this section, all users were divided into four groups according to their educational status. Percentage distribution was made by taking the weighted average of monthly electricity and natural gas consumption of these groups.

Figure 7 shows the change of energy used by households in space heating, cooking, and water heating, according to their educational status.

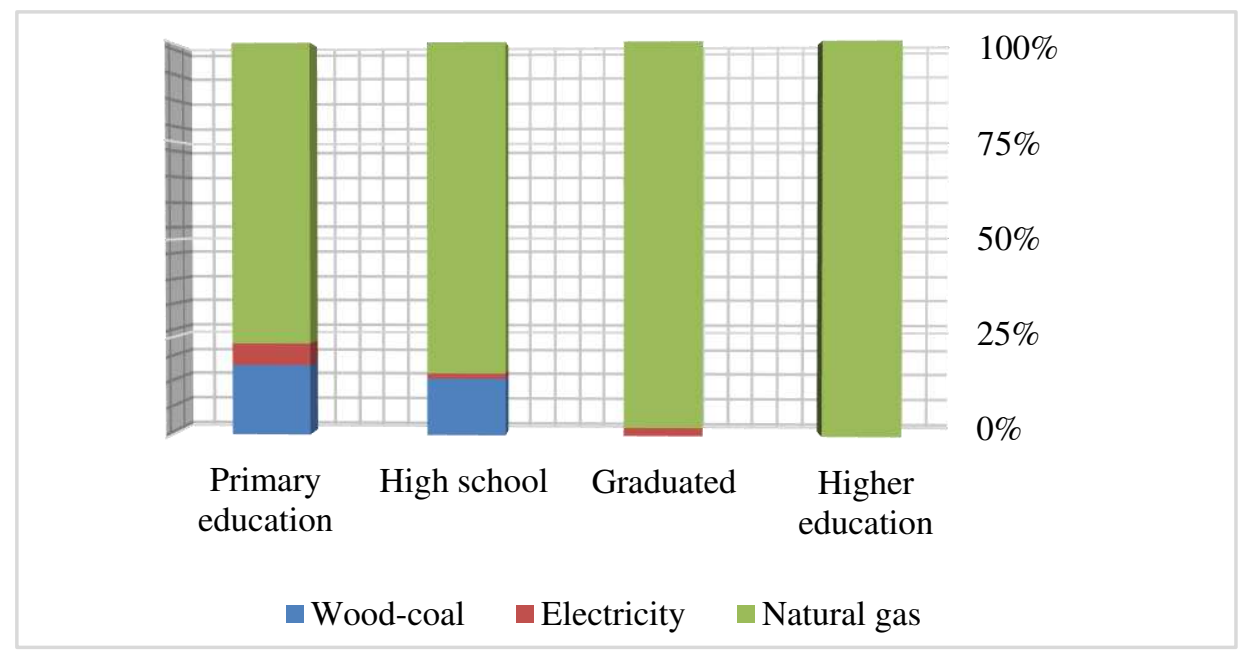

Fig. 7. Fuel use by educational status

It is seen in the chart that all households with a high level of education use clean energy systems such as natural gas. This means that the use of fossil fuels decreases as the level of education increases. It is seen that those who use fossil fuels such as wood are mostly primary and high school graduates, while those who graduate from undergraduate and graduate programs prefer natural gas. From here, it can be said that the level of income increases as the level of education increases, and therefore, access to modern energy systems increases. 


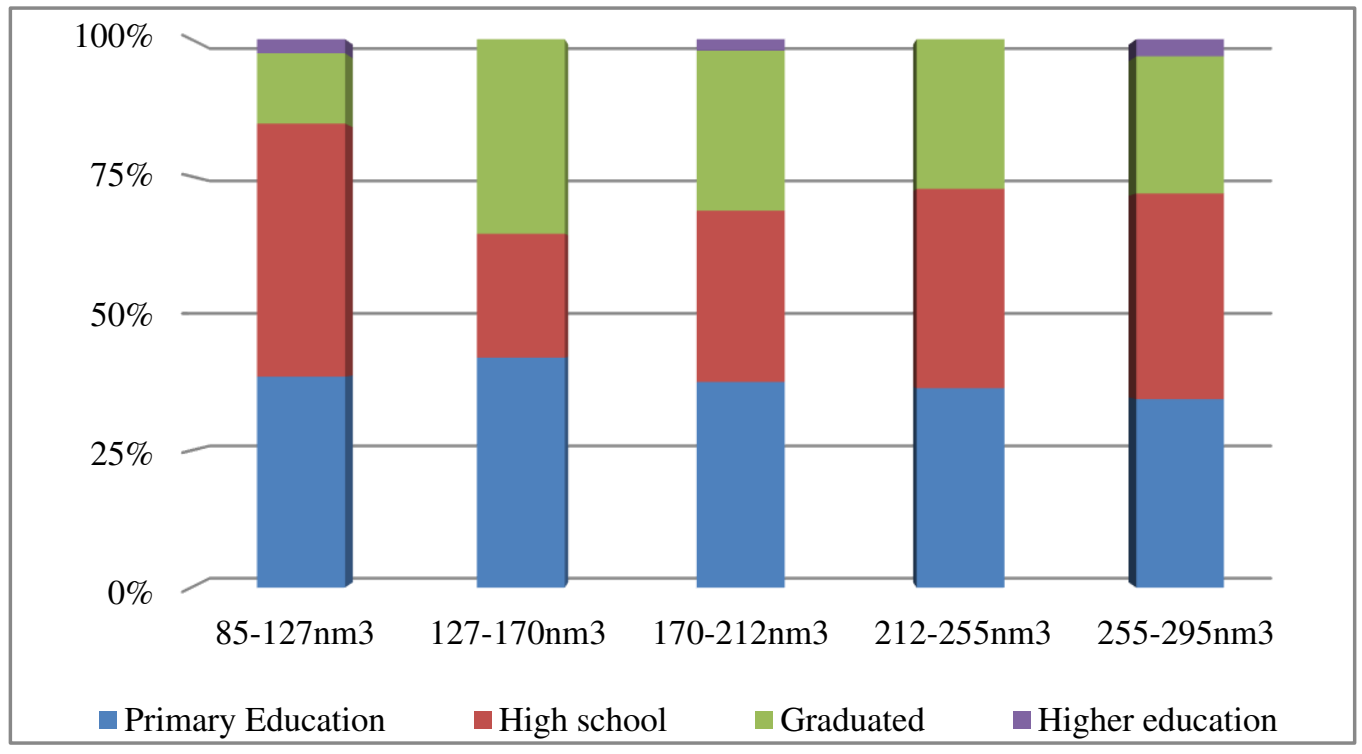

Explanation: $\mathrm{nm}^{3}$ is normal cubic meter.

Fig. 8. Natural gas consumption by educational level

In Figure 8, the distribution of natural gas consumption of households by education level is given. Considering the distribution of natural gas consumption of all education groups, it is seen that there is no homogeneous distribution. According to the results of the survey, it has been observed that households from each education group have access to natural gas consumption at all rates.

Figure 9 shows the percentage of electricity consumption among all survey groups by education level. It has been observed that access to electricity does not change due to the increase in education level. On the contrary, as the education level increased, excess electricity consumption decreased. The following conclusion can be drawn here. The rate of electricity consumption increased only because the level of education increased as the income level increased. The distribution of graduate electricity consumers was considered to be unhealthy, as the proportion of households with higher education in the survey was low. 


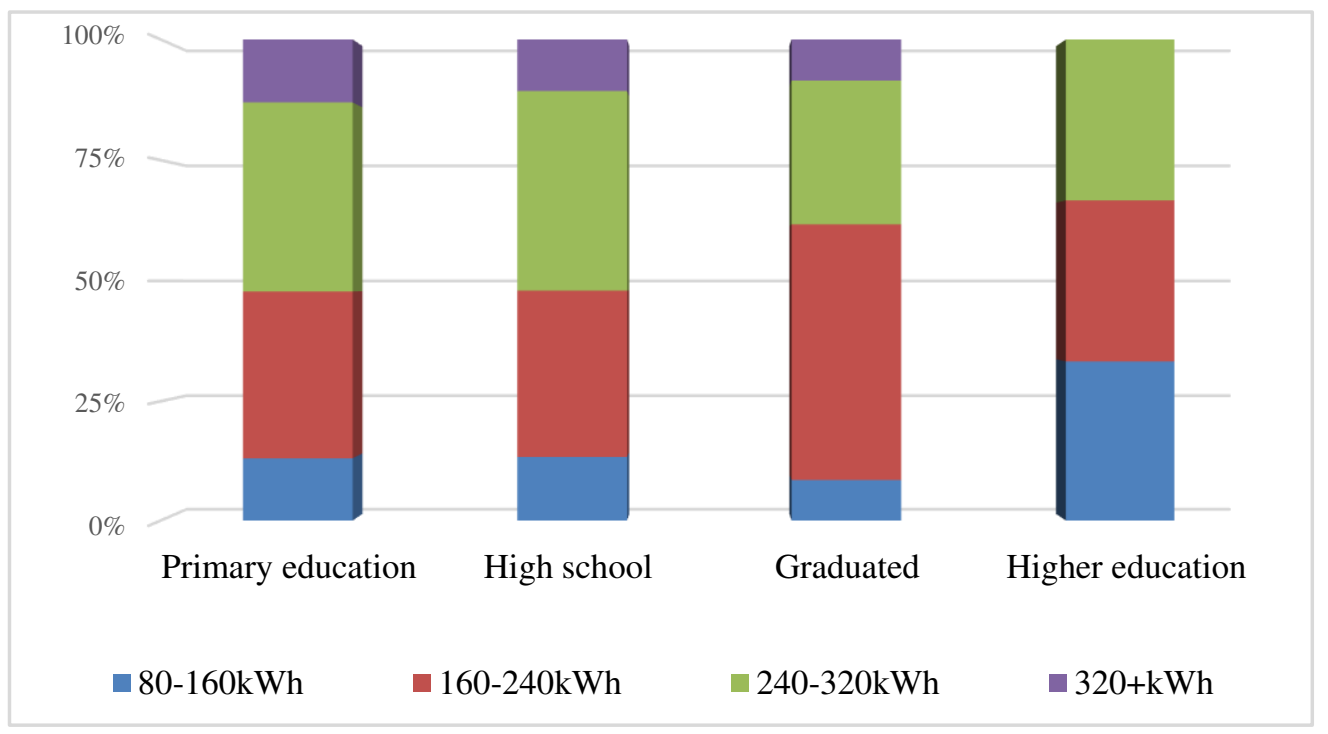

Fig. 9. Electricity consumption by educational status

\section{Conclusion and Policy Implications}

In this study, we evaluated the relationship between modern energy access and the social-economic status of households in urban areas in Turkey's western province of Yalova.

As a case study, it has been investigated to what rate households living in urban areas access electricity and natural gas depending on their education level and income.

Using the data obtained from the 2011 census, we examined the role of socio-economic factors with a survey study in urban energy access.

For this purpose, a survey was conducted covering the Yalova city center area and was made inferences regarding access to energy according to the results of the survey.

These follow:

* The results of the statistical analyses were showed that income inequalities are important to energy access.

* To break the low income cycle of households that lead to insufficient access to modern energy, it is necessary to develop new policies that will improve the income level and increase the educational status.

*In the city center, where access to electricity is not lacking, it has been observed that the inadequacy of households in access to electricity is only due to income difference.

*It has been observed that fossil fuels and derivatives are mostly consumed by low-income and loweducation households. Based on this, it can be said that access to clean energy systems will increase as the income level increases, and the education level increases.

* In Turkey, the results of the objectives set by the government, it has been observed that almost every home has access to natural gas with the widespread use of natural gas in the city center.

* The use of natural gas in the city center is a basic need for all income levels and as the income level of households was increased, consumption was increased but was not change after a certain level.

* In case inequality income level of households problems are not solved, urban poverty can be expected to worsen with the growth in urbanization, and ignoring or forgetting poor households could be the source of a major future problem. Because electricity and natural gas are only a small component of the energy needs of the poor.

*We believe that long-term strategies will be needed to integrate development efforts with energy access issues to create higher income generation opportunities in monetary terms and to make energy supply affordable through the wise use of alternative means. 
Consequently, since these and similar studies are a subject that is largely neglected in the literature, more work is needed to develop a detailed framework and institutional arrangements.

* Also it is necessary to investigate modern energy access for rural areas and villages. If there are any inadequate, new incentives should be introduced.

\section{Availability of data and materials}

The datasets supporting the findings of this study are available from the corresponding author.

\section{Competing interests}

The authors declare no conflict of interest.

\section{Funding}

The funding sponsors had no role in the design of the study; in the collection, analyses, or interpretation of data; in the writing of the manuscript, and in the decision to publish the results.

\section{Author Contributions}

All authors contributed to the discussions presented in this study.

\section{Acknowledgements}

We are grateful to all collaborators and advisors, anonymous referees, and editors of the journal for their useful and constructive comments to revise this article.

\section{Corresponding author}

Correspondence to Gülbahar Bilgiç.

\section{References}

Arl, M., Nazik, H., 2001. Bilimsel araştırmaya giriş. Ankara: Gazi Kitabevi. https://www.pegem.net/kitabevi/326-Bilimsel-Arastirmaya-Giris-kitabi.aspx

Banerjee, R., 2006. Comparison of options for distributed generation in India. Energy Policy 34 (1), 101-111. doi.org/10.1016/j.enpol.2004.06.006

Balc1, A., 2005. Sosyal Bilimlerde Araştırma Yöntem, Teknik ve İlkeler. Pegem Akademi Yayıncilik.

Bhattacharyya, S.C., 2006. Energy access problem of the poor in India: is rural electrification a remedy? Energy Policy 34 (18), 3387-3397. doi.org/10.1016/j.enpol.2005.08.026

Balachandra P., 2011. Dynamics of rural energy access in india: an assessment. Energy-Int J, 36,5556-5567. doi.org/10.1016/j.energy.2011.07.017

Energy atlası http://www.enerjiatlasi.com/dogalgaz-tuketim.

Enerji atlas1, http://www.enerjiatlasi.com/elektrik-tuketimi. 
EPDK, 2015. Strateji Geliştirme Dairesi Başkanlığ 1

http://www.epdk.org.tr/documents/dogalgaz/rapor_yayin/Dpd_Rapor_Yayin_Sektor_Raporu_2013. pdf ANKARA.

Fall. A., Touria S.S., Dafrallah, T., Ndour, A., 2008. Modern energy access in peri-urban areas of West Africa: the case of Dakar, Senegal. Energy for Sustainable Development 12(4), 22-37. doi.org/10.1016/S0973-0826(09)60005-3

Kanagawa, M., Nakata T., 2008. Assessment of access to electricity and the socio-economic impacts in rural areas of developing countries. Energy Policy 36(6), 2016-2029.

doi.org/10.1016/j.enpol.2008.01.041

Mensah G.S, Kemausuor F., Hammond, A.B., 2014. Energy access indicators and trends in Ghana. Renewable and Sustainable Energy Reviews 30, 317-323. doi.org/10.1016/j.rser.2013.10.032

Malaka, Y.,2018. Evaluating the role of rural electrification in expanding people's capabilities in India. Energy Policy 114, 492-498. doi.org/10.1016/j.enpol.2017.12.047

Okada A., Poverty and education H. Esho, M. Hosaka, H. Nogami (Eds.), Series International Development, Nippon-Hyoron-Sha Co., Ltd., Tokyo (2004)

Practical Action. Poor people's energy outlook 2010. Rugby, UK: Practical Action; 2010. https://practicalaction.org/poor-peoples-energy-outlook/

Day R., Walker G., Simcock N., 2016. Conceptualising energy use and energy poverty using a capabilities framework. Energy Policy, 93, 255-264. doi.org/10.1016/j.enpol.2016.03.019 IEA/OECD. World energy outlook 2012. IEA/OECD, Paris; 2012. https://www.iea.org/reports/world-energy-outlook-2012

IEA, 2007. World Energy Outlook 2007. International Energy Agency, Paris, France, (see /http://www.iea.org/textbase/nppdf/free/2007/weo_2007.pdf.)

IEA. 2011. Energy for all: financing energy access for the poor. Special early report on the World Energy Outlook 2011. Paris. https://webstore.iea.org/weo-special-report-2011-energy-for-all

TEİAŞ, Türkiye elektrik iletim ve dağıtım a.ş. websitesi (see http://www.teiaş.gov.tr last visited May 21, 2015)

TUIK, 2011. Population and Housing Census/2013, Turkish Statistical Institute, Printing Division, Ankara July 2013 MTB: 2013-666-100. https://www.tuik.gov.tr/Home/Index

TUIK, 2014. Seçilmiş göstergelerle Yalova, 2013. Turkiye İstatistik Kurumu Matbaas1, Ankara. https://ec.europa.eu/eurostat/documents/7330775/7339623/Turkey+_in_statistics_2015.pdf/317c63 $\underline{86-e 51 c-45 d e-85 b 0-f f 671 e 3760 f 8}$

United Nations. Sustainable energy for all. A vision statement by Ban Ki-Moon, UN SecretaryGeneral. New York: UNEP; 2011. https://www.seforall.org/publications/vision-statement-by-banki-moon-united-nations-secretary-general-november-2011

UNDP, 2011, Human Development Report 2010, United Nations Development Programme, ongoing initiatives by Government, civil societies, and private sector companies to promote modern 
energy services, United Nations Development Programme.

http://hdr.undp.org/sites/default/files/reports/271/hdr_2011_en_complete.pdf

WHO, 2014, Household air pollution and health, Fact Sheet No. 292, World Health Organization. https://www.who.int/news-room/fact-sheets/detail/household-air-pollution-and-health 


\section{Figures}

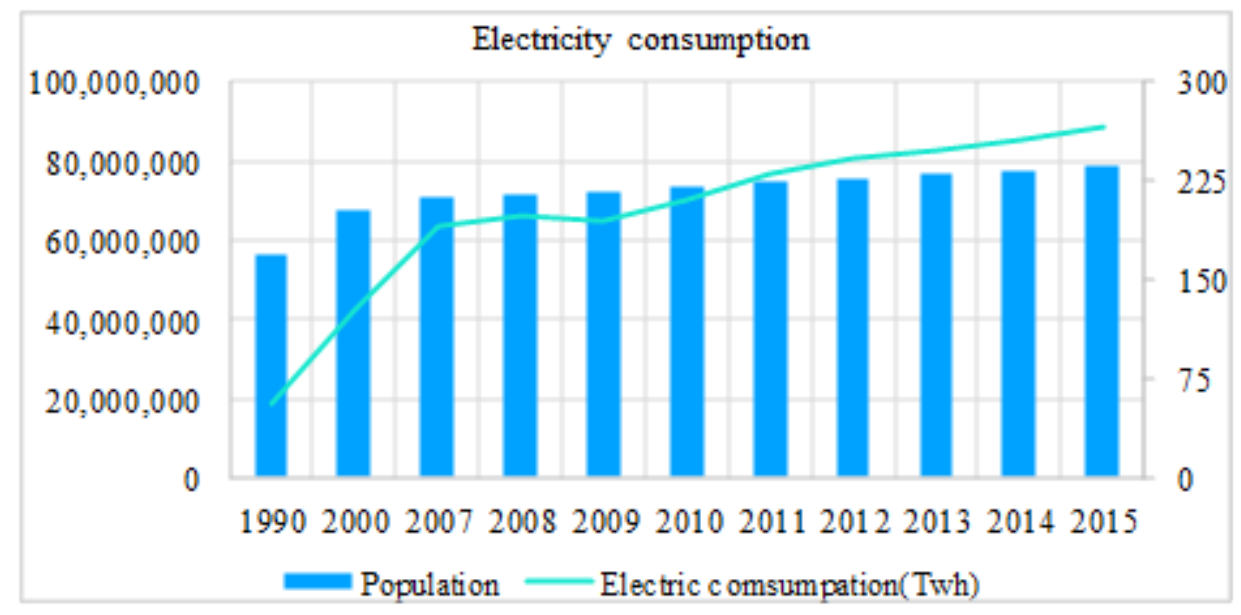

\section{Figure 1}

Electricity access trends in Turkey

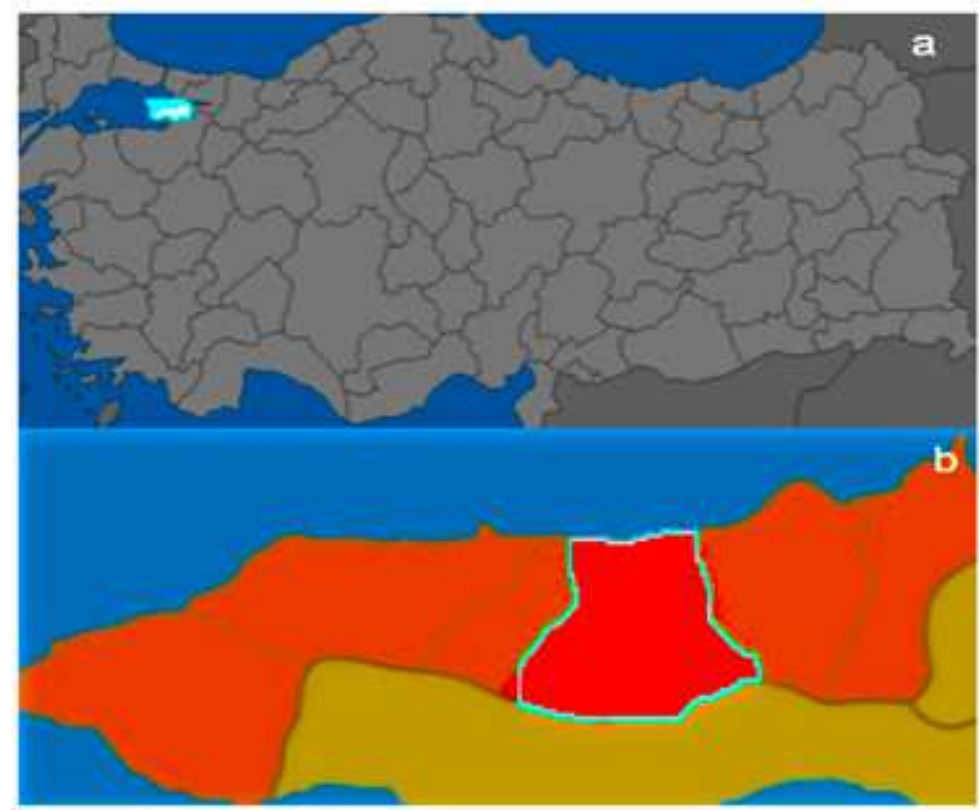

\section{Figure 2}

Map of study area, 1.a Map of Turkey 1.b) Yalova city center area Note: The designations employed and the presentation of the material on this map do not imply the expression of any opinion whatsoever on the part of Research Square concerning the legal status of any country, territory, city or area or of its authorities, or concerning the delimitation of its frontiers or boundaries. This map has been provided by the authors. 


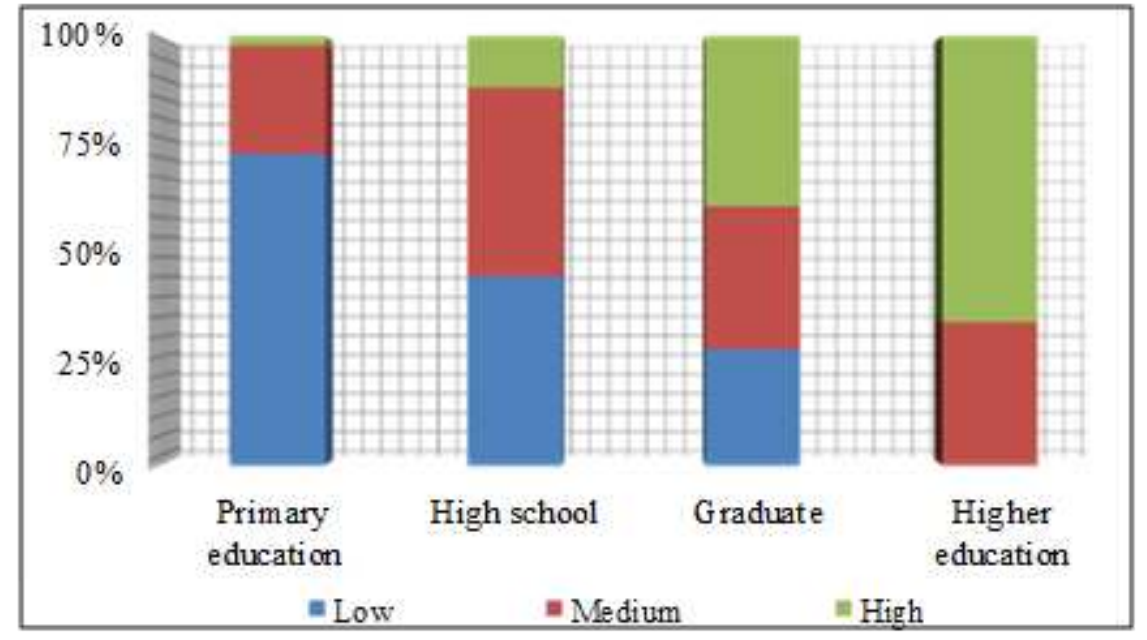

Figure 3

Income level by educational

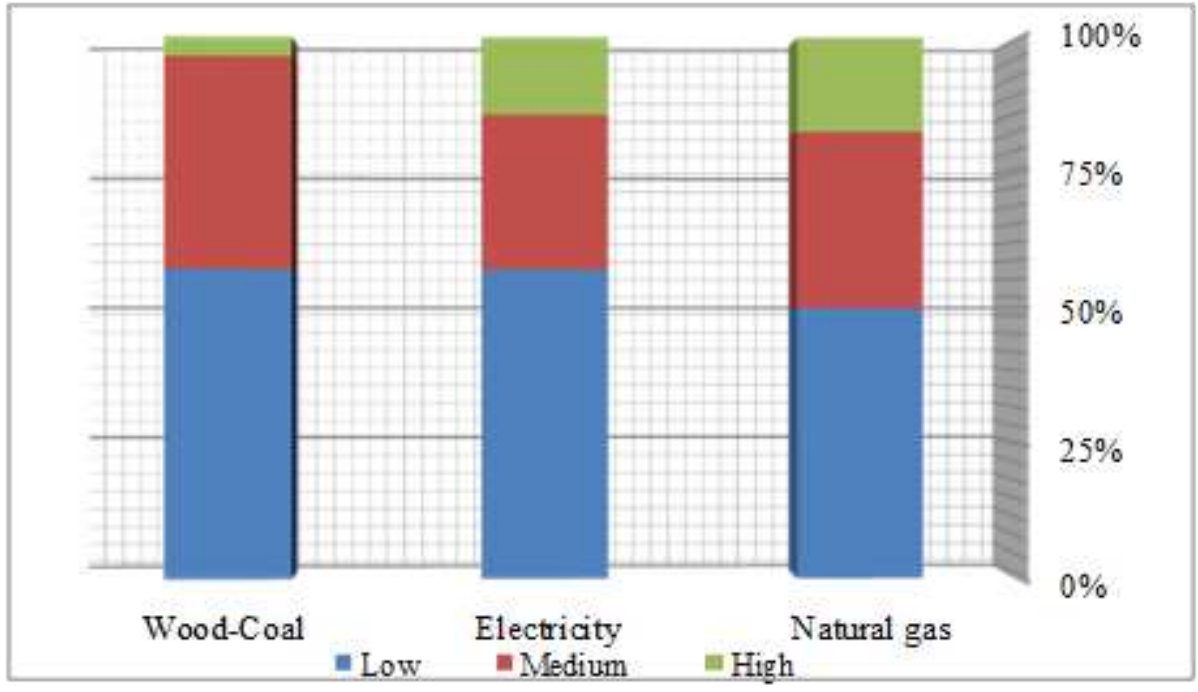

\section{Figure 4}

General fuel consumption by income level

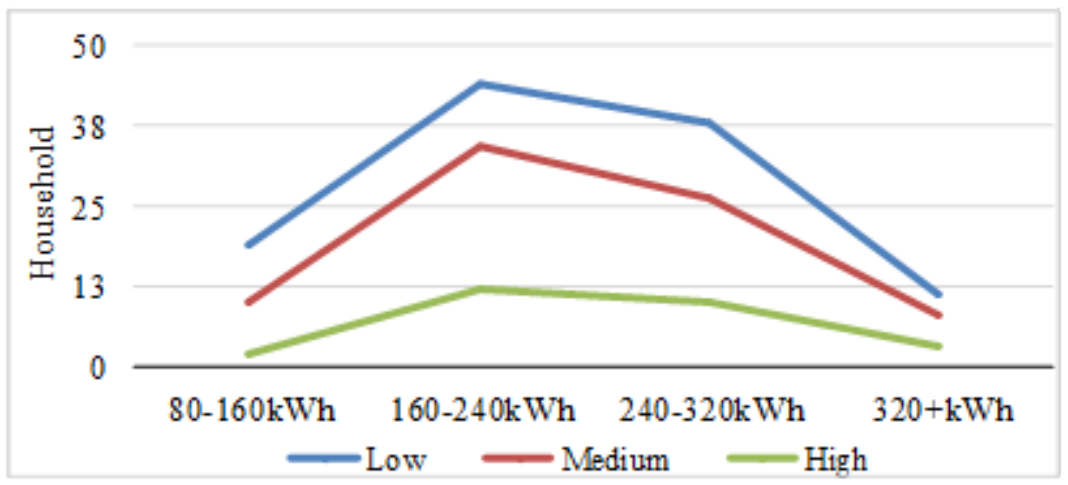

Figure 5 
Change of electricity consumption to income levels of household

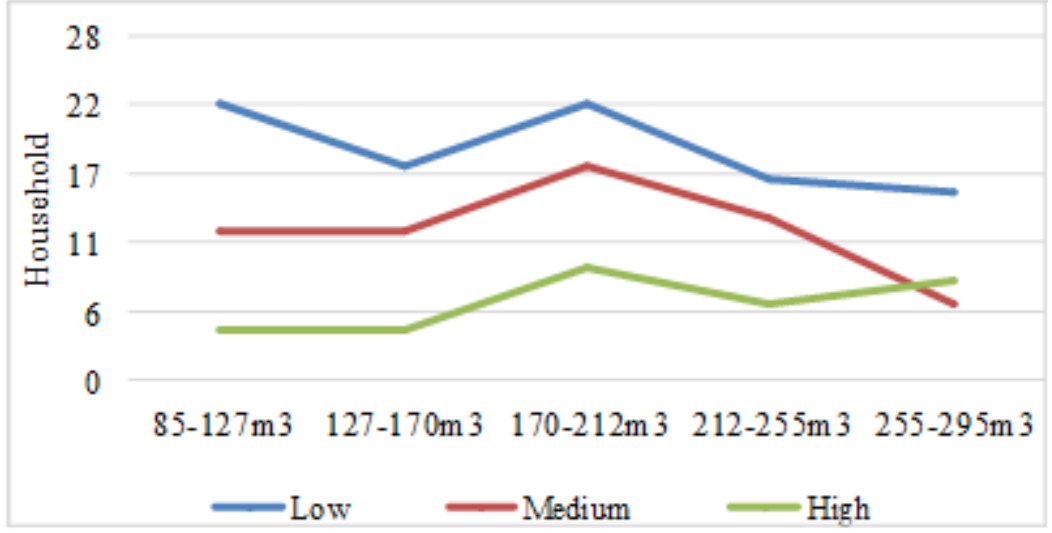

\section{Figure 6}

Natural gas consumption according to household income level

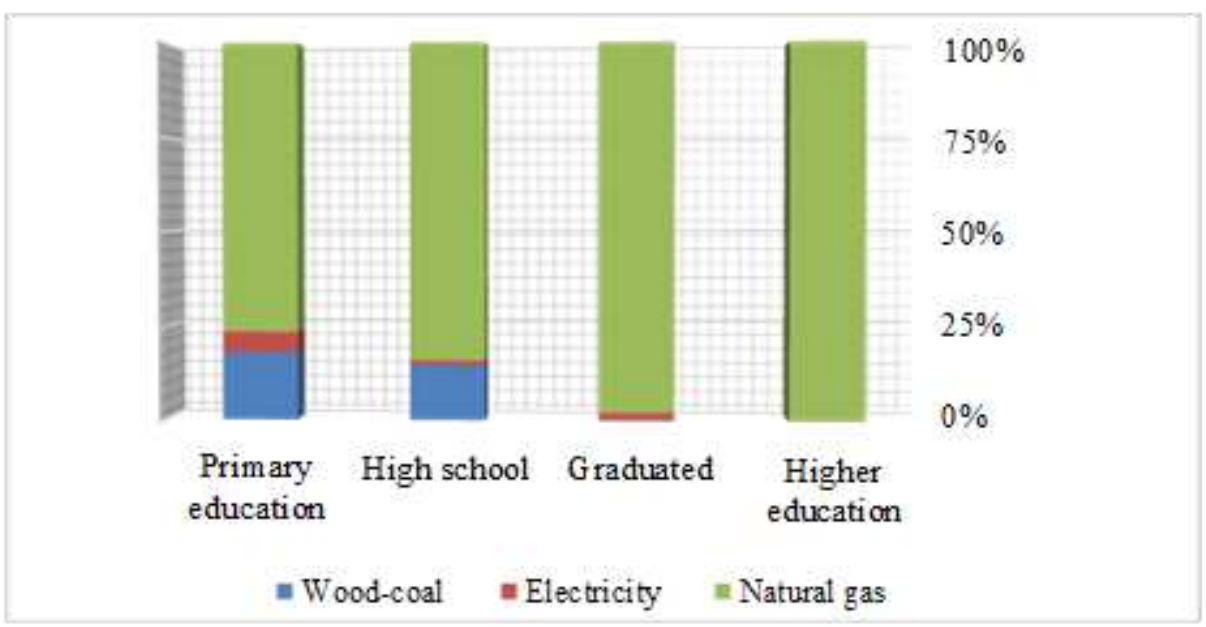

\section{Figure 7}

Fuel use by educational status

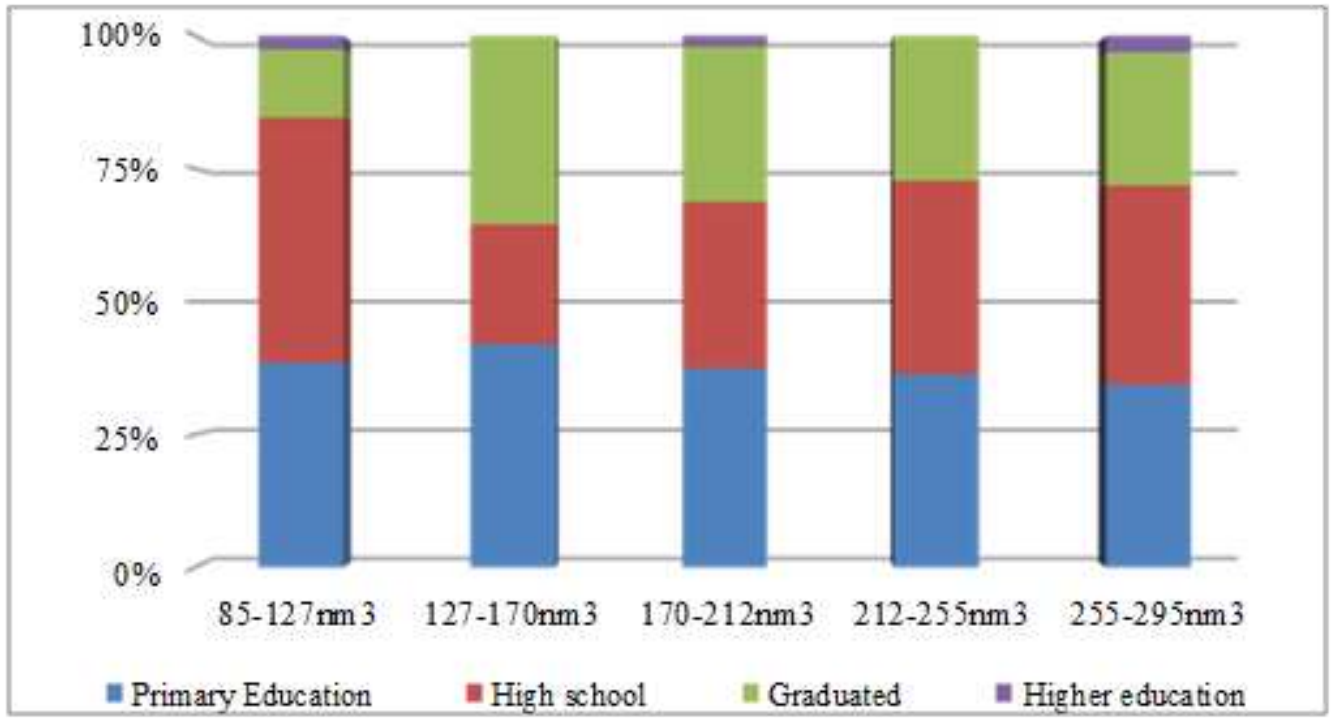


Figure 8

Natural gas consumption by educational level

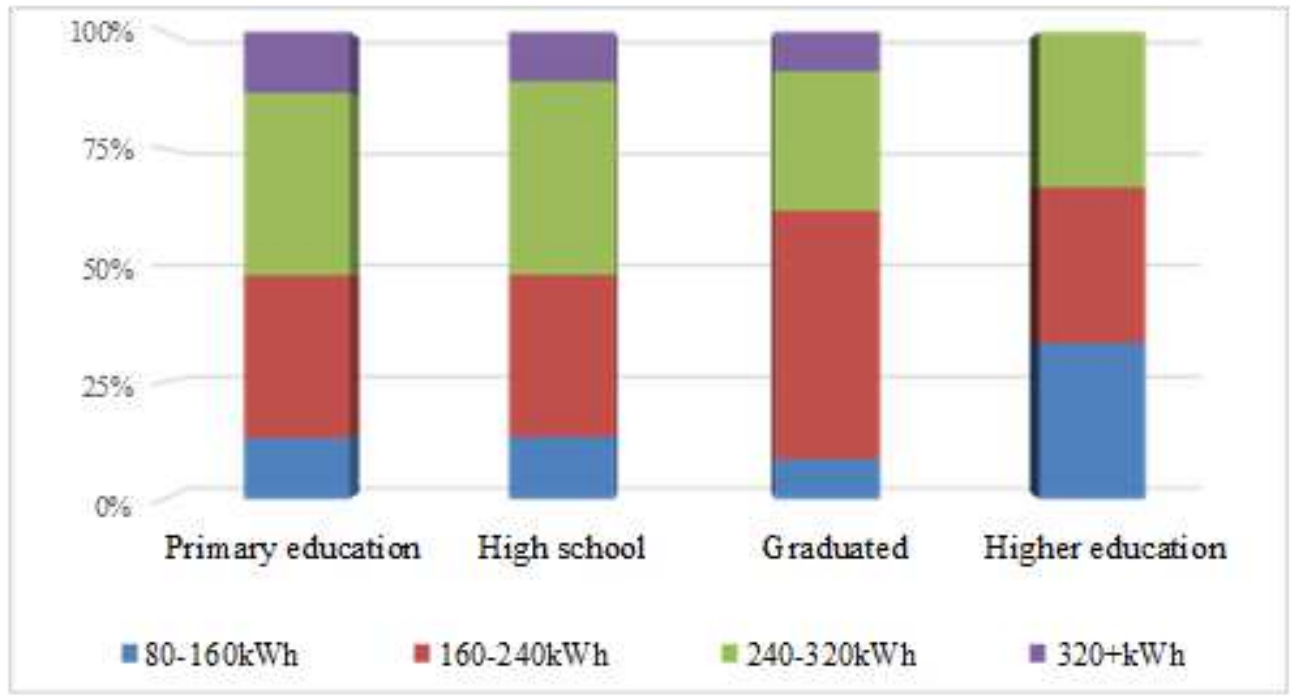

Figure 9

Electricity consumption by educational status 